\title{
Production quality improvement analysis of grey cambric using Six Sigma Method
}

\author{
Yosa Permata Shafira and Agus Mansur \\ Department of Industrial Engineering, Faculty of Industrial Technology, Universitas Islam Indonesia, Jalan Kaliurang Km. 14,5 Sleman, \\ Yogyakarta, Indonesia
}

\begin{abstract}
Quality has an important role in business. A good quality means it is able to meet the required standards. The concept of quality must be comprehensive, whether the quality of the product or its process. PT Textile Yogyakarta is still having a high rate of defect products. The Waste Assessment Model (WAM) was used to identify the wastes that frequently occur by scoring each type of waste. The results show the waste rank are defect $26.12 \%$, inventory $20.36 \%$, motion $15.26 \%$, transportation $14.51 \%$, over production $12.91 \%$, waiting $7.17 \%$, and process $3.67 \%$. While using the Six Sigma from the 4 CTQ process, the result of sigma level is 3.3. It means that the sigma level of PT Textile Yogyakarta is still under the average sigma level in Japan which is 5 Sigma. As for the improvement part, FMEA AHP was used and the results show that the first rank is the uncleaned woof residue, the second rank is the uncut thread which has an RPN value of 8.04 that was caused when the operator did not clean the machine from the woof residue, and the third rank is the malfunctioned machine which has an RPN value of 7.32 that was caused by broken kleting.
\end{abstract}

\section{Introduction}

In 2010 , textile industries were able to employ up to $11 \%$ of total industrial workforce or 1.34 million people in 2,853 companies throughout Indonesia and donate up to 8.9 percent of total domestic exports. Until 2014, the realization of textile industry investment in Indonesia reached $\mathrm{Rp} 9.53$ trillion or it grew $9.4 \%$ from the previous year [1]. To sustain the growth, it needs a trigger to boost the competitiveness based on work productivity. Quality is everything that satisfies the customer and fits the requirements [2]. Product quality is the key to win the market competition, because it can earn the customer's trust to the product offered by the company, then in the end it will lead to customer loyalty.

Quality problems are often experienced by all kinds of companies, including PT. Tekstil Yogyakarta which frequently encounters defected cloth on the finished goods. To cope with that problem, the company should optimize the quality control to minimize the amount of defected goods and ensure the finished goods to meet the required standards of quality in the company. Quality control should not only focus on the finished goods, but also the whole process of production starting from the raw materials, work-in-process goods, and finished goods ready to be sold. Based on this background, the aim of this research is to analyze the quality control of the highest defect in PT Tekstil Yogyakarta from September 2016 to February 2017 using the Six Sigma DMAIC method.

\section{Basic Theory}

Alkatiri et al. [4] explains that by combining Six Sigma with seven tools such as fishbone diagram, pareto diagram and histogram is able to analyze and identify causes of defects product so it can be reduced [3]. As the result of analysis on textile and garment industry in PT SSP is known the cause of DPMO (Defect Per Million Opportunity) average value and sigma value before implementation of 6,523,27 and 3,98 sigma. DPMO average value and sigma value after implementation of $4,753.80$ and 4,09 sigma in other words the average DPMO decreased by $27.13 \%$ and the sigma value increased by 0.11 sigma [4].

Further research on six sigma obtained the result of increasing the sigma value from the previous 3.05 to 3.80 sigma and the defective product defect by $29.87 \%$ [5]. The improvement is done by applying Failure Mode Effect and Analys is method and statistical process control (SPC). Failure Modes and Effects Analysis (FMEA) is able to identify the risk of failure that occurred during the production process in making sarong weaving at PT. Asaputex Jaya [6]. Integrates Lean Six Sigma with other statistical tools can extend effectiveness and sustain improvements. This study compares the performance before and after the implementation of the proposed solution for waste reduction by integrating with Analytic Hierarchy Process (AHP) the objective is to analyze and assess the effect of the highest waste causes to increase effectiveness [7].

\footnotetext{
* Corresponding author: agusmansur@uii.ac.id
} 


\section{Method}

The phases of this research are referring to Gasperz to settle problems and enhance the process using the DMAIC (Define, Measure, Analyze, Improve, Control).

\subsection{Define}

It is the goal setting phase of the Six Sigma quality improvement activities. This phase determines the plans that have to be done to carry out the improvement of each stage in the key business process [8]. This phase will identify the waste by using the Waste Assessment Model (WAM) which can show the relations of each waste and how the rank of defect types occurred so they can be minimized [9]. After that, this phase should be continued by arranging the diagram of SIPOC (Suppliers, Inputs, Process, Outputs and Customers) which summarize the input and output from one process to another, in the form of a table. Then finally this phase should determine the Critical to Quality.

\subsection{Measure}

It is the second phase as an effort to improve the quality of Six Sigma that measure the control chart and performance baseline. Furthermore, the U chart is used as the control chart to find out whether the defected goods of the resulting product are within the required limits or not. Performance baseline measurement uses the measurement unit of sigma level to detect the level position of the company which indicated by PPM (Part per Million Opportunities) value. PPM is the number of defected goods in a million opportunities [10].

\subsection{Analyze}

This phase will analyze the process capability by using the cause and effect diagram or also known as fishbone. This diagram establishes ways to make better products and how to reach the best results.

\subsection{Improve}

This phase is used as an effort to improve production quality. FMEA gives best solution after the analyze phase, while AHP has a mathematic approach to find out the right solution $n$. One of the weaknesses of FMEA is the possibility of earning the same RPN value with different nt purposes. It causes the relative importance value of Severity, Occurrence and Detection should be considered by integrating the FMEA with the AHP method.

\section{Result and Discussion}

\subsection{Define}

\subsubsection{Waste Identification}

The results of Waste Assessment Model (WAM) show the rank of waste from the highest to lowest percentage respectively, i.e. defect $26.12 \%$, inventory $20.36 \%$, motion $15.26 \%$, transportation $14.51 \%$, overproduction $12.91 \%$, waiting $7.17 \%$ and process $3.67 \%$. By referring the Pareto principle $80 / 20$ which means that $20 \%$ of the cause is responsible for $80 \%$ of the problem, the waste type that has to be the taken to analyze is Defect.

\subsubsection{SIPOC Diagram}

Identifying the key processes in Six Sigma method can be done by creating a process model Suppliers - Input Process - Outputs - Customers or SIPOC diagram. Figure 1 shows the diagram SIPOC for the production process of grey cloth.

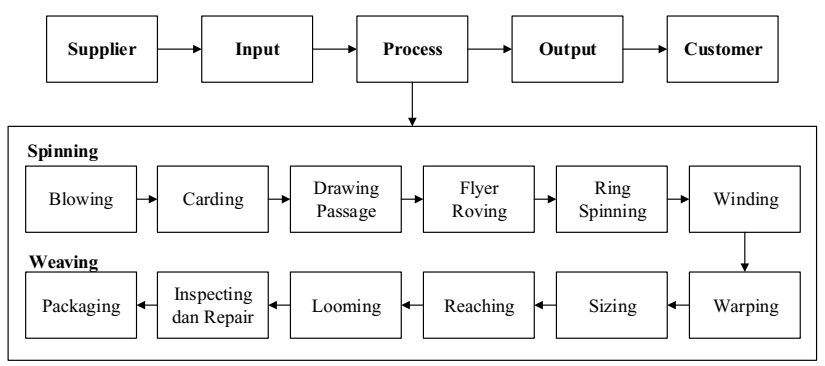

Fig 1. SIPOC diagram

\subsubsection{Critical to Quality}

Identification is done towards the quality characteristics that have potential in causing the defected goods 217 . The quality characteristics of this research are the types of defected goods that affect the output.

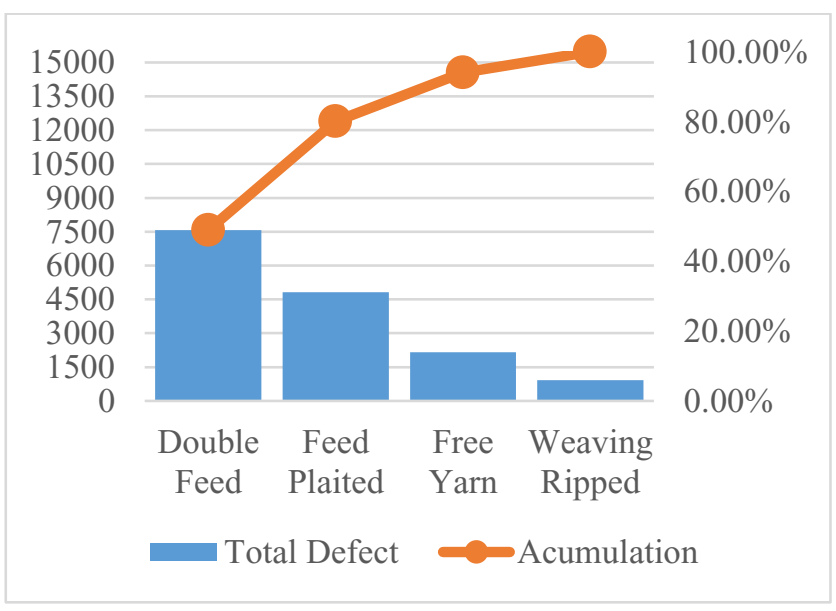

Fig 2. Diagram Pareto CTQ 217 


\subsection{Measure}

\subsubsection{U Chart}

Chart control has median value which is the average of the quality characteristics or value of the defects proportion which relates to controlled situation, and horizontal lines called the Upper Control Limit (UCL) and the Lower Control Limit (LCL) [11]. A process is called as controlled if the data is between the LCL and UCL. The reason why this research uses the $\mathrm{U}$ Chart is because the data which are defective in one product may have more than one type of defects with the sample value (n) used is not constant.

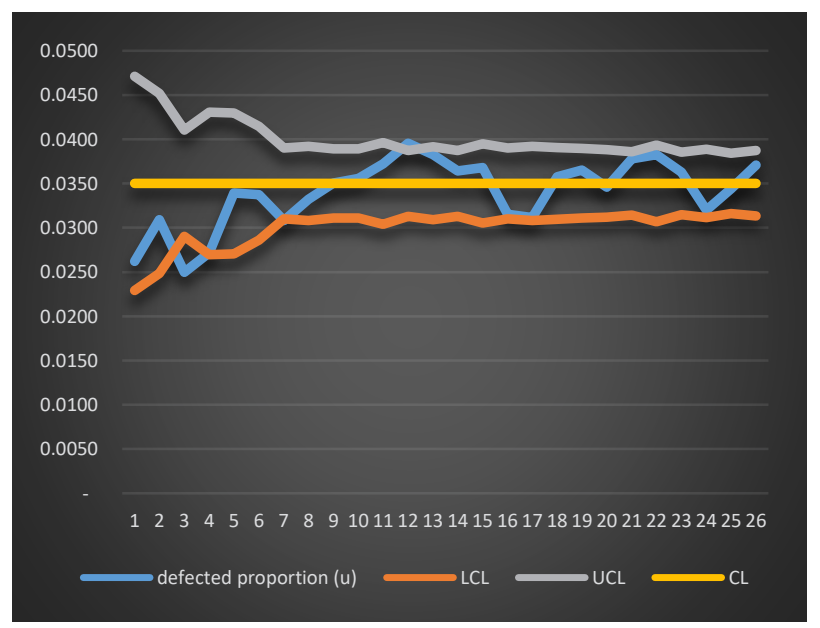

Fig 3. U chart

Based on the figure above, it is known that the data is not consistent, which there are some data above and under control. Data that has the cause of special variations should be removed. As the data in September where the number of machines used is below average, the data outside the control limit must be removed. Meanwhile, for data that has no special cause variations is maintained. Calculation during the September 2016 - February 2017 shows the average value or the center line is at 0.03522 .

\subsubsection{Baseline Measurement}

Performance baseline measurement at the output level was carried out directly on the final product to find out how far the final outputs of the process meet the specific needs of the customer, before they are handed over to the customer. The performance baseline outcome measurement used in Six Sigma is the level of PPM (Parts per Millions) and sigma level. Based on the calculation, the average value of the PPM is $34,412.00$ with sigma value 3.32 . This indicates that the possibility of $34,412.00$ units of defected goods occurred per one millio $\mathrm{n}$ events. The sigma value is categorized in the sigma level of 3 and if it is analyzed using the COPQ (Cost of Poor Quality) table by Gaspersz (2005) it will cause 25\% - 40\% losses of sales.

\subsection{Analyze}

Based on CTQ that has been determined and the calculation that has been done, it can be identified the root cause of the problem by using a fishbone diagram. It will help to find out what actions to solve the causes of the problem. The figure below is an example of the fishbone diagram of each defect:

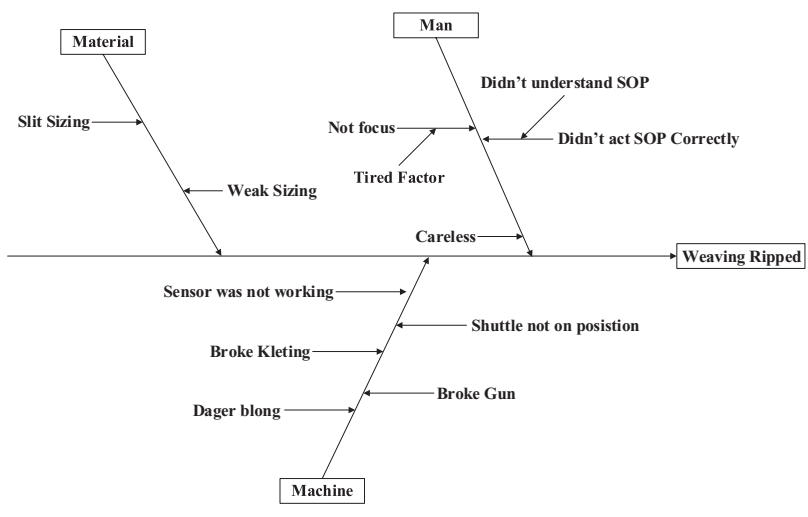

Fig 4. Fishbone of weaving ripped

\subsection{Improve}

It is generally a technique used for product and process design, by identifying the potential failures and prioritizing them, subsequently reducing the errors in the process. A successful FMEA activity helps a team to identify potential failure modes, based on past experience with similar products or processes [12]. The conventional calculation of FMEA method is weighing the Severity (S), Occurrence (O), and Detection (D) proportionally. One of its weaknesses is the possibility of earning the same RPN value with different purposes. Meanwhile, in reality, those criteria may have different weight [13]. Therefore, the relative importance value of Severity, Occurrence and Detection should be considered by integrating with AHP method.

Tabel 1. Consistency ratio

\begin{tabular}{|c|c|c|c|c|c|}
\hline $\begin{array}{c}\text { Matrix } \\
\text { Multiplication }\end{array}$ & Eugen Value & $\boldsymbol{\kappa}$ maks & CI & IR & CR \\
\hline 0.54 & 3.02 & \multirow{2}{*}{3.03} & 0.01 & 0.58 & 0.03 \\
\hline 0.21 & 3.01 & & & & \\
\hline 2.29 & 3.06 & & & & \\
\hline 3.05 & 9.09 & & & & \\
\hline
\end{tabular}

Conventional FMEA RPN:

Severity $x$ Occurrence $x$ Detection

FMEA AHP RPN:

$(W S x S)+(W O x O)+(W D x D)$ 
Tabel 2. Conventional FMEA and FMEA AHP

\begin{tabular}{|c|c|c|c|c|c|c|c|c|c|c|c|}
\hline \multirow[b]{2}{*}{ Potential Failure Mode } & \multirow[b]{2}{*}{ CODE } & \multicolumn{5}{|c|}{ Conventional FMEA } & \multicolumn{5}{|c|}{ FMEA AHP } \\
\hline & & SEV & $o c c$ & $D E T$ & $R P N$ & RANK & $\begin{array}{l}S E V \\
0.18\end{array}$ & $\begin{array}{l}O C C \\
0.07 \\
0.07\end{array}$ & $\begin{array}{l}D E T \\
0.75\end{array}$ & $R P N$ & RANK \\
\hline Not focus & $\mathrm{FI}$ & 5 & 3 & 3 & 45 & 17 & 5 & 3 & 3 & 3.36 & 17 \\
\hline $\begin{array}{l}\text { Careless } \\
\text { Dont understand SOP }\end{array}$ & $\begin{array}{l}\mathrm{F} 2 \\
\mathrm{~F} 3\end{array}$ & $\frac{3}{5}$ & 3 & 3 & $\begin{array}{l}45 \\
45\end{array}$ & $\begin{array}{l}17 \\
17\end{array}$ & ${ }_{5}^{5}$ & 3 & 3 & $\begin{array}{l}3.36 \\
3.36 \\
36\end{array}-5$ & $\begin{array}{l}17 \\
17\end{array}$ \\
\hline Silt Sizing & $\mathrm{F} 4$ & 9 & 3 & 6 & 162 & 7 & 9 & 3 & 6 & 6.33 & 5 \\
\hline Weak Sizing & F5 & 9 & 3 & 6 & 162 & 7 & 9 & 3 & 6 & 6.33 & 5 \\
\hline $\begin{array}{l}\text { Pallet Double } \\
\text { Cone dobel }\end{array}$ & $\begin{array}{l}\mathrm{F} 6 \\
\mathrm{~F} 7\end{array}$ & $\begin{array}{l}6 \\
6\end{array}$ & ${ }_{3}^{6}$ & $\begin{array}{l}6 \\
6 \\
\end{array}$ & ${ }_{108}^{216}$ & $\begin{array}{l}5 \\
9 \\
9\end{array}$ & ${ }_{6}^{6}$ & ${ }_{3}^{6}$ & $\begin{array}{l}6 \\
6 \\
6\end{array}$ & 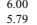 & $7_{9}^{7}$ \\
\hline The initial scrolls are woven & F8 & 6 & 6 & 6 & 216 & 5 & 6 & 6 & 6 & 6.00 & 7 \\
\hline $\begin{array}{l}\text { Broken Feed } \\
\text { Baining yarm is } \mathrm{n}\end{array}$ & F9 & $9^{9}$ & 6 & 6 & 324 & ${ }^{3}$ & 9 & 6 & 6 & 6.54 & 4 \\
\hline $\begin{array}{l}\text { The remaningig yarn is not cut } \\
\text { offt }\end{array}$ & F10 & 9 & 6 & 8 & 432 & 1 & 9 & 6 & 8 & 8.04 & 1 \\
\hline Remaining Feed from Batery & FII & 9 & 6 & 8 & 432 & 1 & 9 & 6 & 8 & 8.04 & 1 \\
\hline & F12 & 5 & 3 & 6 & 90 & 10 & 5 & 3 & 6 & 5.61 & 10 \\
\hline & $\mathrm{F} 14$ & & $3_{3}^{3}$ & 6 & $\begin{array}{l}90 \\
90\end{array}$ & $\begin{array}{l}10 \\
10 \\
10\end{array}$ & 5 & $\begin{array}{l}3 \\
3\end{array}$ & 6 & & 10 \\
\hline & & & & & & 10 & 5 & & & & \\
\hline Machine is not function & F16 & 5 & $3^{3}>>-2$ & 6 & 90 & 10 & 5 & 3 & 6 & 5.61 & 10 \\
\hline & Fin & $5^{5}$ & 等 & 6 & 列 & 10 & $s_{5}^{5}$ & $3_{3}^{3}$ & 6 & $\begin{array}{c}5.61 \\
5.61\end{array}$ & 年 \\
\hline & $\begin{array}{l}\text { F19 } \\
\text { Fis } 19\end{array}$ & 5 & 6 & 8 & 240 & 4 & 5 & 6 & 8 & 7.32 & 3 \\
\hline & $\mathrm{F} 20$ & 5 & 3 & 3 & 45 & 17 & 5 & 3 & 3 & 3.36 & 17 \\
\hline
\end{tabular}

The conventional FMEA and FMEA AHP have the different priorities in determining what causes of defect are priorities that must be solved first.

\section{Conclusion and Recommendation}

1) The results of the Waste Assessment Model show that the highest waste is defect $26.12 \%$ with 4 defect types that frequently occur, i.e. double feed, remaining feed, free yarn and weaving ripped.

2) Based on measurement obtained average sigma value are 3.32. The sigma value included in the sigma 3 and it will losses of $25-40 \%$ of sales.

3) Implementing 5S (Seiri, Seiton, Seiso, Seiketsu, Shitsuke) to eliminate or minimize the waste in the working environment.

4) Adding the fast reed warp protector to ensure that the shuttle is in place and if there is a change or it is out of position, the machine will stop automatically.

5) Adding photo cell censors that capable to detect the passing weft, therefore it will stop automatically when the feed is cut.

6) To minimize the human error, the company can use the Poka Yoke anti-fault device by making special control board completed with tools image for operator, therefore the production process can be done correctly and meet the required standards.

\section{References}

1. BKPM, "Peluang Investasi," 26 Desember 2016. [Online]. Available:

http://www.bkpm.go.id/id/peluanginvestasi/peluang-berdasarkan-sektor/industri.

2. V. Gaspersz, (2003)

3. H. A. Alkatiri, H. Adianto and D. Novirani, Reka Integra Itenas, 3, 148-159, (2015)

4. H. A. Alkatiri, H. Adianto and D. Novirani, 3 (2015)

5. S. K. Dewi, Jurnal Teknik Industri UMM, 43-50, (2012)

6. N. B. Puspitasari and A. Martanto, J@TI Undip, 9398, (2014)

7. M. K. Hassan, American Journal of Industrial Engineering, 1, 28-35, (2013)

8. V. Gaspersz, Pedoman Implementasi Program Six Sigma Terintegrasi dengan ISO: 2000, (2005)

9. I. A. Rawabdeh, International Journal of Operations \& Production Management, 25, 800-822, (2005)

10. N. R. R. C. Pande, The Six Sigma Way: Bagaimana GE, Motorola dan Perusahaan Terkenal Lainnya Mengasah Kinerja Mereka, (2002)

11. H. Purnomo, Pengantar Teknik Industri, II, (2004)

12. V. S. Kamble and T. Z. Quazi, (2014)

13. R. K. Aslani, H. R. Feili and H. Javanshir, Management Science Letters, 1981-1984, (2014) 